\title{
Detection of the ichthyotoxic dinoflagellate Gyrodinium (cf.) aureolum and morphologically related Gymnodinium species using monoclonal antibodies: a specific immunological tool
}

\author{
Engel G. Vrieling ${ }^{1}$, Louis Peperzak ${ }^{2}$, Winfried W. C. Gieskes ${ }^{3}$, Marten Veenhuis $^{4}$ \\ ${ }^{1}$ Department of Marine Biology and Laboratory of Electron Microscopy, University of Groningen, Biological Centre, \\ Kerklaan 30, 9751 NN Haren, The Netherlands \\ ${ }^{2}$ Tidal Waters Division, National Institute for Marine and Coastal Management (RIKZ), PO Box 8039, 4330 EA, Middelburg, \\ The Netherlands \\ ${ }^{3}$ Department of Marine Biology, University of Groningen, Biological Centre, Kerklaan 30, 9751 NN Haren, The Netherlands \\ ${ }^{4}$ Laboratory of Electron Microscopy, University of Groningen, Biological Centre, Kerklaan 30, 9751 NN Haren,
}

The Netherlands

\begin{abstract}
Sixteen monoclonal antibodies which recognize different cell surface antigens of the ichthyotoxic marine dinoflagellate Gyrodinium of aureolum were prepared and characterized for use in identification by both immunofluorescence microscopy and flow cytometry. Based on the labeling results obtained from indirect immunofluorescence assays the monoclonals could be divided into 3 groups: (I) fluorescence of the overall cell surface, (Il) fluorescence of the overall cell surface together with the flagella, and (III) fluorescence of granular-like structures randomly distributed along the cell surface and at the edges of the sulcus and cingulum. Cross-reactivity of 6 selected monoclonals with other phytoplankton species revealed that labeling was restricted to G. aureolum/G. cf. aureolum and to the morphologically closely related species Gymnodinium nagasakiense and G. mikimotoi. This suggests a taxonomic proximity of these species. Fixation of samples with paraformaldehyde produced the optimal immunochemical response, resulting in the strongest fluorescence intensities. In flow cytometric analyses, labeled cells of $G$. cf. aureolum could be distinguished sufficiently from unlabeled controls when monoclonals of Group II and a pooled serum (combined antibodies of Groups I, II, and III) were used. This immunochemical technique will be applied in an early warning system to detect $G$. aureolum cells at dilute concentrations using flow cytometry or, alternatively, image analysis.
\end{abstract}

KEY WORDS: Flow cytometry - Gymnodinium (cf.) aureolum - Immunofluorescence - Monoclonal antibodies · Toxic marine phytoplankton

\section{INTRODUCTION}

The number of reports on the occurrence of nuisance and potentially toxic bloom-forming phytoplankton species has increased steadily during the last decades (Anderson 1989, Hallegraeff 1993). Although the bloom frequency may be overestimated due to increased observer efforts, other factors (eutrophication and other forms of pollution, general climatological changes) have been implicated (Smayda 1989). In fact, the toxic dinoflagellate genera Gyrodinium, Gymnodinium, and Alexandrium have been observed in sam- ples taken in Dutch coastal waters only since 1989 (Peperzak 1990, R. P. T. Koeman pers. comm.), while they have been reported before in other parts of the North Sea (Reid et al. 1990). Dinophysis species have been observed before in Dutch coastal waters (Kat 1985, 1987, Leewis 1985); the presence of other toxic species remains elusive.

The presence of a harmful species is usually not observed until the full bloom stage, after biotoxins or anoxia have already exerted their effects on sea life or humans. A study of the initial stages of such a bloom would have revealed the ecophysiological conditions 
leading to mass occurrence. This would have allowed prediction and modeling of the harmful event. In order to detect potentially toxic phytoplankton species at dilute concentrations - the early bloom stage - an early warning system is now being developed for Dutch coastal waters. This method is based on specific immunochemical tagging of specific organisms which are subsequently enumerated by flow cytometry (Vrieling et al. 1993a, b). To differentiate morphologically closely related toxic and non-toxic phytoplankters within genera, several antisera have already been prepared (e.g. Hiroishi et al. 1988, Nagasaki et al. 1989, 1991, Sako et al. 1992, Bates et al. 1993). These antisera recognize cell surface antigens of the red tide organisms Chattonella, Gymnodinium and Alexandrium, and discriminate toxic from non-toxic diatoms of the Nitzschia complex at the species level. For our own early warning system, species-specific antisera are essential to achieving unequivocal identification of a target organism in order to avoid cross reactions with other species present in the mixed populations to be analyzed by flow cytometry.

In this paper we describe the preparation and characterization of monoclonal antibodies directed against cell surface antigens of Gyrodinium (cf.) aureolum (= $G$. auroleum or $G$. cf. auroleum). Attention is focused on this species because of its potential threat to young shellfish at oyster and mussel grounds in parts of the Dutch coastal region.

\section{MATERIALS AND METHODS}

Preparation of monoclonal antibodies. Unialgal batch cultures of the dinoflagellate Gyrodinium cf. aureolum Hulburt (strain Iroise; F. Partensky, Roscoff, France) were established in f/2-Si enriched seawater medium (Guillard \& Ryther 1962) at a temperature of $16^{\circ} \mathrm{C}$ under a light/dark regime of $12 \mathrm{~h}: 12 \mathrm{~h}$ (light intensity of approximately $75 \mu \mathrm{E} \mathrm{m}^{-2} \mathrm{~s}^{-1}$ ). Exponentially growing cells were fixed in situ for $2 \mathrm{~h}$ at room temperature by adding freshly prepared paraformaldehyde at a final concentration of $2 \%(w / v)$. Subsequently, the cells were harvested by mild centrifugation (5 min, $1000 \mathrm{rpm}$ ), and washed 3 times with sterile phosphate-buffered saline (PBS) containing $0.02 \%$ $(\mathrm{w} / \mathrm{v})$ azide. Samples were resuspended, stored at $-70^{\circ} \mathrm{C}$ and washed twice with sterile PBS before immunization.

Monoclonal antibodies were prepared with the assistance of MCA Development BV, Groningen, The Netherlands. Aliquots of $100 \mu \mathrm{l}$ (approximately $10^{4}$ cells) were used to immunize $4 \mathrm{BALB} / \mathrm{C}$ mice ( 3 to $4 \mathrm{wk}$ old) by intraperitoneal injections at Days 0,30 , and 60 respectively. Freund's complete adjuvant was used
(1:1) at Day 0, while at Days 30 and 60, cells were emulsified in incomplete Freund's adjuvant. Serum samples of all immunized mice were screened for antibody reactivity towards target Gyrodinium cf. aureolum cells using indirect immunofluorescence (see below). One mouse, whose antiserum expressed the highest titer, was selected for fusion. At Day 90 (4 d before fusion) this individual was boosted with an intravenous injection of another $10^{4}$ cells, before it was sacrificed. Suspended spleen cells were used for fusion with mouse myeloma cells of an SP20 HAT-sensitive cell line, using PEG-4000 and HAT selection. Fused cells were spread as oligoclones into 96-well microtiter plates and grown for $2 \mathrm{wk}$ before a screening procedure (see below) was performed. After screening, positive oligoclonal hybridomas were cloned by limiting dilution in culture media to ensure monoclonality and stability of the cells. Specific antibody-producing clones were expanded by sequential transfer to $100 \mathrm{ml}$ culture flasks

Immunofluorescence. After fusion and cloning, specific antibody-producing hybridoma cells were screened by an indirect immunofluorescence method (Vrieling et al. 1993a) using supernatants of 10 to $15 \mathrm{~d}$ old oligo- and monoclonals. This vacuum manifold assay was slightly modified for application of the Multi Screen Assay System (Millipore Intertech). Multiscreen 96-well microtiter plates, containing a permeable bottom of nitrocellulose filter $(0.45 \mu \mathrm{m}$ pore size), were filled with $100 \mu \mathrm{l}$ cell suspension (about $10^{4} \mathrm{cells}$ ), which were fixed in situ with $2 \%(\mathrm{w} / \mathrm{v})$ paraformaldehyde (Vrieling et al. 1993a) and blocked with incubation buffer [PBS to which $1 \%(\mathrm{w} / \mathrm{v})$ bovine serum albumin was added]. Target cells were incubated for $1 \mathrm{~h}$ at room temperature after addition of hybridoma supernatants (at a 1:2 dilution). After incubation, supernatants were filtered through the nitrocellulose filter and wells were washed with three $200 \mu \mathrm{l}$ volumes of incubation buffer. Subsequently, wells were loaded with $100 \mu \mathrm{l}$ of incubation buffer containing $2 \%(\mathrm{v} / \mathrm{v})$ of sheep anti-mouse IgG (Amersham) conjugated with fluorescein isothiocyanate (FITC). After incubation for 45 min at room temperature, wells were again vacuum-washed 3 times with $200 \mu \mathrm{l}$ PBS. Labeled cells were resuspended in $50 \mu \mathrm{PBS}$ before fluorescence was examined by both epifluorescence microscopy and real time confocal laser scanning microscopy (Vrieling et al. 1993a).

The titer of the polyclonal antisera of the immunized mice and the resulting 16 monoclonal antibodies was determined by running dilution series using the modified multiscreen immunofluorescence assay as described above. Preservation methods were evaluated for their effect on immunofluorescence intensities according to the procedures of Vaulot et al. (1989) and 
Bates et al. (1993). In all immunofluorescence labeling experiments controls were performed by omitting the primary antisera to estimate non-specific labeling of the secondary antiserum.

Cross-reactivity. Six monoclonal antibodies (GA1, GA2, GA7, GA8, GA14 \& GA15) were tested in duplicate in the immunofluoresence assay described above to determine the specificity with respect to different strains of Gyrodinium (cf.) aureolum and other phytoplankton species. Species used in these cross-reactivity experiments are listed in Tables $3 \& 4$. They were cultured in $\mathrm{f} / 2$ medium (Si was omitted for nondiatoms) under the same conditions as $G$. cf. aureolum (see above). Additional samples of various strains of the naked dinoflagellates Gyrodinium and Gymnodinium were obtained elsewhere either fixed $(1.0 \%$ glutaraldehyde or $2.0 \%$ paraformaldehyde) or live. Finally, some prefixed $(4.0 \%$ Lugol's iodine) and stored $\left(4^{\circ} \mathrm{C}\right)$ field samples, taken in 1991 in the Dutch monitoring program, were used for immunochemical identification of $G$. (cf.) aureolum.

Flow cytometry. For flow cytometry, cells were fixed with $2 \%(\mathrm{w} / \mathrm{v})$ paraformaldehyde and examined with the Optical Plankton Analyzer (Dubelaar et al. 1989 , Peeters et al. 1989), using the filter settings as described previously (Vrieling et al. 1993a). G. cf. aureolum cells were examined under 4 different labeling conditions: (1) labeled with GA2, (2) labeled with GA8, (3) labeled with GA15, and (4) labeled by a pooled serum consisting of equal amounts of GA2, GA8, and GA15. This last condition was used to examine the fluorescence intensity of the FITC probe by coupling the probe to the antigens recognized by all antibodies. Green FITC fluorescence (FBG; measured between 520 and $544 \mathrm{~nm}$ ) and red chlorophyll autofluorescence (FBR; measured between 650 and $750 \mathrm{~nm}$ ) of unlabeled cells and cells at all labeling conditions were compared both in bivariate plots of green vs red fluorescence and in histograms of events vs green fluorescence.

\section{RESULTS}

\section{Monoclonal antibodies}

Five oligoclonal hybridomas, producing antibodies directed against cell surface antigens of Gyrodinium cf. aureolum, were identified by the modified vacuum manifold immunofluorescence assay. These hybridomas were cloned and expanded, after which 16 antibody producing clones, designated as GA1 to GA16, were selected and cultured to obtain $100 \mathrm{ml}$ batches of monoclonal antibodies which were used for further characterization.
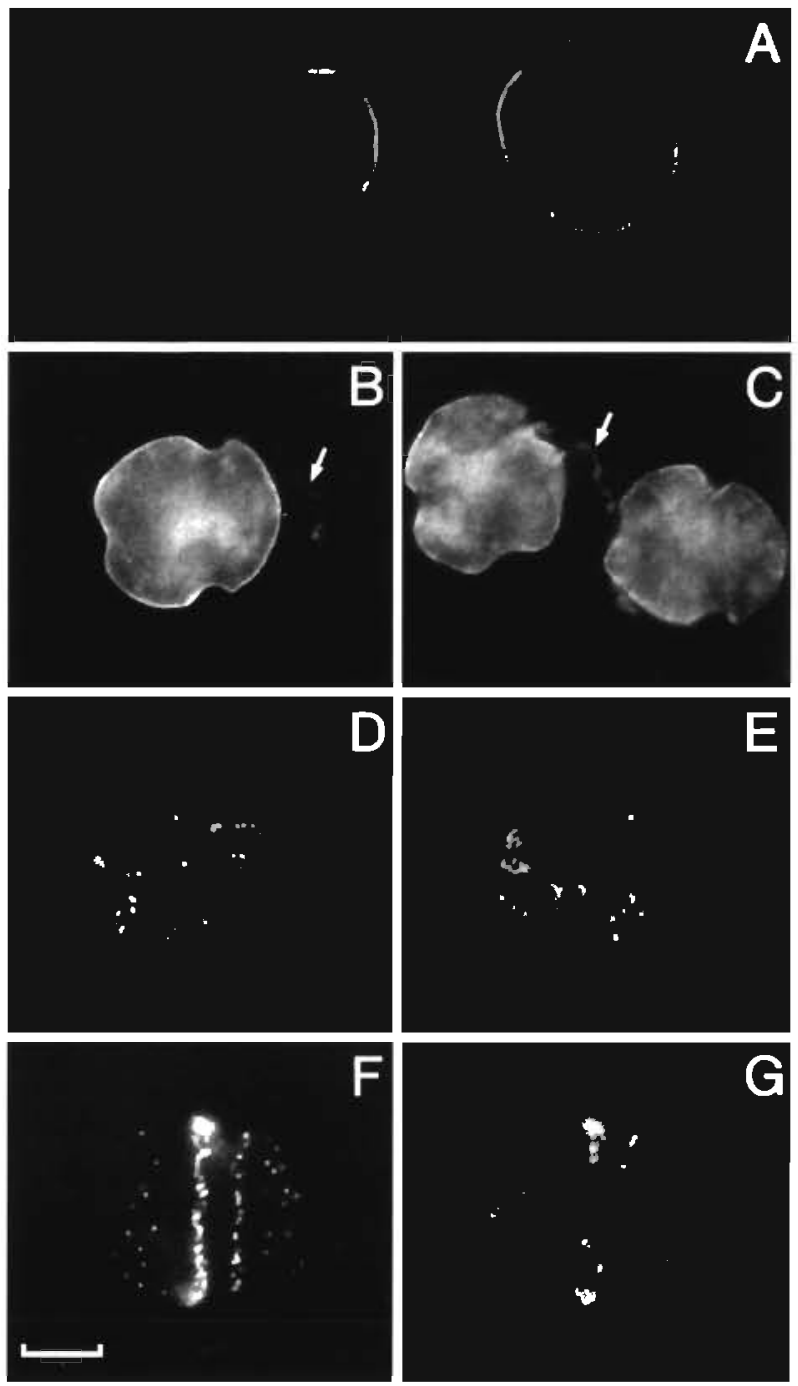

Fig. 1. Gyrodinium cf, aureolum. Micrographs of dinoflagellates treated with indirect immunofluorescence using the monoclonals GA2, GA8 \& GA15. FITC fluorescence is confined to the outer cell wall. (A) Monoclonal GA2 shows bright fluorescence of the outer cell wall. (B \& C) GA8 shows bright fluorescence of outer cell wall and flagella (arrows). (D to G) GA15 shows bright fluorescence of granular particles randomly distributed along the cell wall, the sulcus and cingulum. (F \& G) Aligned globular-like fluorescence at the edge of the sulcus and especially the cingulum of the same cell at different focal positions. Scale bar $=20 \mu \mathrm{m}$

As judged from immunofluorescence microscopy, the labeling patterns of Gyrodinium cf. aureolum cells varied among the monoclonals, so they could be divided into 3 separate groups. Group I (GA1 \& GA2) only showed reactivity with the outer cell surface (Fig. 1A) and differed from Group II (GA3 to GA8) which showed the same fluorescence pattern, though at an enhanced intensity, but the flagella showed a bright fluorescence as well (Fig. 1B, C). Group III (GA9 to GA16) revealed a random spotted fluorescence pattern 
on the outer cell surface; in addition the sulcus showed fluorescence (Fig. 1D, E). Fluorescent particles appeared to be concentrated specially at the edges of the cingulum, which was evident after moving through several focal planes (Fig. 1F, G). In control experiments non-specific labeling of the secondary antiserum was absent (not shown).

To select suitable monoclonal antibodies and to define the optimal dilution, the titer of all 16 clones was determined. Two monoclonal antibodies of each of the 3 groups indicated above were selected based on titer, fluorescence intensities, and number of cells labeled (Table 1). The titer is defined as the reciprocal of the highest dilution at which clear FITC fluorescence could be observed (designated as + in Table 1, i.e. over $40 \%$ of the cells showing positive labeling) and distin-

Table 1 Titers of 6 selected monoclonal antibodies directed against cell surface antigens of Gyrodinium cf. aureolum. The titers represent the reciprocal of the dilution of the antibodies. Intensity of the immunochemical reaction is expressed as: $(+++) 80$ to $100 \%$ of the cells stained, $(++) 60$ to $80 \%,(+) 40$ to $60 \%$, and $(-)<40 \%$

\begin{tabular}{|rccccccc|}
\hline \multirow{2}{*}{ Titer } & \multicolumn{8}{c}{ Immunofluorescence reactivity } \\
& \multicolumn{2}{c}{ Group I } & \multicolumn{2}{c|}{ Group II } & Group III \\
& GA1 & GA2 & GA7 & GA8 & GA14 & GA15 \\
\hline 25 & +++ & +++ & +++ & +++ & +++ & +++ \\
50 & ++ & ++ & +++ & +++ & ++ & ++ \\
100 & ++ & ++ & +++ & +++ & + & ++ \\
200 & + & + & ++ & ++ & + & + \\
400 & + & + & + & + & - & - \\
800 & - & + & + & + & - & - \\
1600 & - & - & + & - & - & - \\
2400 & - & - & - & - & - & - \\
\hline
\end{tabular}

guished from chlorophyll autofluorescence. The titers of the antibodies in Groups I \& II varied between 400 and 800 , while those of Group III showed a broader variation, ranging from 25 to 200 (not all are listed in Table 1).

\section{Cell preservation methods and influence on anti- genicity}

The effects of different preservation methods on antigenicity, expressed as the ability of antigens to bind to the different antibodies, are summarized in Table 2. Paraformaldehyde and formalin fixation displayed high intensities of FITC fluorescence with all monoclonals tested; in addition a bright red fluorescence of chloroplasts was evident. Glutaraldehyde fixation caused partial inhibition of binding (Table 2). In addition to a decrease of fluorescence intensities, an interfering intracellular yellow-greenish background fluorescence appeared (not shown). Also, the antibodies of Group III failed to react with the antigens (Tables 2 \& 3) fixed with glutaraldehyde. Freezing at $-80^{\circ} \mathrm{C}$ did not significantly affect antigen binding by Group I \& II monoclonals, although the intensity of the fluorescence signal was weaker compared to paraformaldehyde or formalin fixation. Frozen cells were damaged and had probably lost the antigens recognized by the antibodies of Group III (Table 2). Prefixation prior to freezing the cells resulted in quite satisfactory fluorescence intensities, although glutaraldehyde still affected the immunochemical reaction of monoclonal antibodies of Group III (Table 2). Lugol fixation fully destroyed the binding capacity of the antibodies, except for those of Group II (GA7 \& GA8).
Table 2. Comparison of effects of various conservation methods on the immunofluorescence reaction among 6 selected monoclonals (2 of each group) and Gyrodinium of aureolum. Antibody dilution 1:50. Intensity is expressed as in Table 1

\begin{tabular}{|c|c|c|c|c|c|c|c|}
\hline \multirow[t]{2}{*}{ Fixative } & \multirow[t]{2}{*}{ Strength } & \multicolumn{6}{|c|}{ Immunofluorescence reactivity } \\
\hline & & GAI & GA2 & GA7 & GA 8 & GA14 & GA15 \\
\hline Formalin & $2.0 \%$ & + & + & +++ & t+t & ++ & ++ \\
\hline Frozen, $-80^{\circ} \mathrm{C}$ & - & + & + & ++ & ++ & - & - \\
\hline Frozen (prefixed)": & $2.0 \%$ & ++ & ++ & +++ & +++ & ++ & ++ \\
\hline Frozen (prefixed) ${ }^{\mathrm{t}}$ & $0.5 \%$ & + & + & ++ & ++ & - & - \\
\hline Glutaraldehyde & $0.5 \%$ & + & + & ++ & ++ & - & - \\
\hline Glutarald./paraformald. & $2.0 \%$ & + & + & +++ & +++ & - & - \\
\hline Lugol's iodine & $4.0 \%$ & - & - & ++ & ++ & - & - \\
\hline Paraformaldehyde & $2.0 \%$ & ++ & ++ & +++ & +++ & ++ & ++ \\
\hline
\end{tabular}

\section{Cross-reactivity of the antibodies to other species}

From specificity and cross-reactivity experiments it became clear that all selected monocionals reacted with Gyrodinium (cf.) aureolum and the morphologically closely related species Gymnodinium nagasakiense and Gymnodinium mikimotoi (Table 3). The fluorescence labeling pattern of all these species was the same as shown for $G$. cf. aureolum (Fig. 1). Other representatives of naked dinoflagellates did not react and antibodies of Group III failed to react with glutaraldehyde-fixed cells (Table 3 ), as expected from the data presented 
Table 3. Reactivity of 6 selected monoclonal antibodies with different strains of Gyrodinium aureolum, the closely related species Gymnodinium nagasakiense and G. mikimotoi, and other members of both dinoflagellate taxa. Antibody dilution 1:50. Intensity is expressed as: $(+++)$ very intensive, $(++)$ intensive, $(+)$ clearly visible, and $(-)$ not detectable. (GA): prefixed in $0.5 \%$ glutaraldehyde solution (see 'Materials and methods')

\begin{tabular}{|c|c|c|c|c|c|c|c|}
\hline \multirow[t]{2}{*}{ Species } & \multirow[t]{2}{*}{ Strain } & \multicolumn{6}{|c|}{ Immunofluorescence reactivity } \\
\hline & & GA1 & GA2 & GA7 & GA8 & GA14 & GA15 \\
\hline \multicolumn{8}{|l|}{ Gymnodinium spp. } \\
\hline G. catenatum & CCMP412 & - & - & - & - & - & - \\
\hline G. catenatum (GA) & D5 & - & - & - & - & - & - \\
\hline G. galatheanum & CCMP415 & - & - & - & - & - & - \\
\hline G. mikimotoi & AUSTRALIA & + & + & +++ & +++ & + & + \\
\hline G. nagasakiense & KATSUURA & + & + & ++ & ++ & + & + \\
\hline G. nagasakiense & BUZEN85-2 & + & + & ++ & ++ & + & + \\
\hline G. nagasakiense (GA) & $G-303-a \times 2$ & + & + & ++ & ++ & - & - \\
\hline G. cf. nagasakiense (GA) & TINDUFF & + & + & ++ & ++ & - & - \\
\hline G. simplex & CCMP418 & - & - & - & - & - & - \\
\hline G. varians & CCMP421 & - & - & - & - & - & - \\
\hline Gymnodinium sp. ${ }^{a}$ & $Y-100$ & - & - & - & - & - & - \\
\hline \multicolumn{8}{|l|}{ Gyrodinium spp. } \\
\hline G. aureolum (GA) & CCMP429 & + & + & ++ & ++ & - & - \\
\hline G. aureolum (GA) & CCMP430 & + & + & ++ & ++ & - & - \\
\hline G. aureolum & PLY497a & ++ & ++ & +++ & +++ & ++ & ++ \\
\hline G. aureolum & SKAGERRAK & ++ & ++ & +++ & +++ & + & + \\
\hline G. aureolum & TS175GA & ++ & ++ & +++ & +++ & ++ & ++ \\
\hline G. cf. aureolum & IROISE & ++ & ++ & +++ & +++ & ++ & ++ \\
\hline G. instriatum & CCMP431 & - & - & - & - & - & - \\
\hline G. rugosum ${ }^{2}$ & GRUGW301 & - & - & - & - & - & - \\
\hline G. uncatenatum & CCMP1310 & - & - & - & - & - & - \\
\hline
\end{tabular}

in Table 2. The specifity of the monoclonals was examined further by testing various phytoplankton species of other taxonomic groups (Table 4). For all the species studied so far, significant labeling was invariably absent. In natural mixed populations, only cells of $G$. aureolum reacted. Occasionally, green autofluorescence of cell walls of small heterotrophic dinoflagellates was observed.

\section{Flow cytometry}

The selected monoclonal antibodies were also examined for their use in flow cytometric studies. Labeled cells of Gyrodinium cf. aureolum were readily distinguished from unlabeled controls in the case of monoclonals of Group II and the pooled serum (red clusters in Fig. 2B, D). For the monoclonals of Groups $1 \&$ III an insufficient increase of green FITC fluorescence was noticed, resulting in an almost complete overlap of the clusters in bivariate plots of labeled and unlabeled cells (Fig. 2A, C). Histograms of the number of events versus linear green fluorescence revealed that the sep- aration of the labeled cells from unlabeled controls could readily be observed (Fig. 3). In these histograms labeled cells are easily recognized by their separated peaks for antisera of Group II and the pooled antiserum (arrows in Fig. 3C, D), while the peaks of cells labeled with monoclonals of Groups I \& III almost disappeared in the peak of controls (arrows in Fig. 3A, B).

\section{DISCUSSION}

For the specific detection of Gyrodinium (cf.) aureolum 16 monoclonal antibodies directed against cell surface antigens were prepared. By indirect immunofluorescence these monoclonals were divided into 3 different groups based on differences in localization of the fluorescent probe (FITC) after their use (Fig. 1). The major difference between the monoclonals placed in Group I (clones GA1 \& GA2) and Group II (clones GA3 to GA8) is that those of Group II were recognized by flagella antigens (Fig. 1C). A granular surfacebound fluorescence pattern was observed using antibodies of Group III (GA9 to GA16); this pattern proba- 
Table 4. Cross-reactivity of 6 selected monoclonal antibodies ( 2 of each group) with various phytoplankton species, as judged from the reaction in an immunofluorescence assay. Antibody dilution 1:50. All strains were fixed with paraformaldehyde. Intensity is expressed as in Table 3 . nd: not determined

\begin{tabular}{|c|c|c|c|c|c|c|c|}
\hline \multirow[t]{2}{*}{ Species } & \multirow[t]{2}{*}{ Strain } & \multicolumn{6}{|c|}{ Immunofluarescence reactivity } \\
\hline & & GA1 & GA2 & GA7 & GA8 & GA14 & GA 15 \\
\hline \multicolumn{8}{|l|}{ Bacillariophyceae } \\
\hline Asterionella japonica & CCRUGAj & - & - & - & - & - & - \\
\hline Cyclotella sp. & CCRUGCY & - & - & - & - & - & - \\
\hline Chaetoceros sp. & CCRUGCh & - & - & - & - & - & - \\
\hline Ditylum brightwelli & CCRUGDb & - & - & - & - & - & - \\
\hline Nitzschia closterium & CCRUGNC & - & - & - & - & - & - \\
\hline Thalassiosira sp. & T135Thsp & - & - & - & - & - & - \\
\hline T. pseudonana & CCMP1335 & - & - & - & - & - & - \\
\hline$T$ weissflogï & CCMP1049 & - & - & - & - & - & - \\
\hline \multicolumn{8}{|l|}{ Chlorophyceae } \\
\hline \multirow{2}{*}{\multicolumn{8}{|c|}{ Cryptophyceae }} \\
\hline & & & & & - & - & - \\
\hline \multicolumn{8}{|l|}{ Cyanophyceae } \\
\hline Synechococcus & CCMP1334 & - & - & - & - & - & - \\
\hline \multicolumn{8}{|l|}{ Dinophyceae } \\
\hline Alexandrium tamarense & PCC173 & - & - & - & - & - & - \\
\hline A. tamarense & CCMP115 & - & - & - & - & - & - \\
\hline Prorocentrum lima & CCMP685 & - & nd & - & - & - & nd \\
\hline P. micans & T135MC1 & - & - & - & - & - & - \\
\hline P. micans & ELBR & - & - & - & - & - & - \\
\hline P. minimum & W4OMN1 & - & - & - & - & - & - \\
\hline P. minimum & W4OMN2 & - & - & - & - & - & - \\
\hline P. redfeldii & W4ORED & - & - & - & - & - & - \\
\hline Scripsiella trochoidea & OSCHSCl & - & - & - & - & - & - \\
\hline \multicolumn{8}{|l|}{ Haptophyceae } \\
\hline Chrysochromulina polylepis & CCMP286 & - & - & - & - & - & - \\
\hline Emiliania huxleyi & $\mathrm{L}$ & - & - & - & - & - & - \\
\hline Isochrysis galbana & CCMP1323 & - & - & - & - & - & - \\
\hline Phaeocystis sp. (Antarctica) & $Y$ & - & - & - & - & & - \\
\hline Phaeocystis sp. (Antarctica) & W & - & - & - & - & - & - \\
\hline Phaeocystis sp. (North Sea) & $\mathrm{K}$ & - & - & - & - & - & - \\
\hline \multicolumn{8}{|l|}{ Prasinophyceae } \\
\hline Micromonas pusilla & CCNIOZ & - & - & - & - & - & - \\
\hline Pyramimonas sp. & FLYNN & - & - & - & - & - & - \\
\hline P. disomata & E250PD1 & - & - & - & - & - & - \\
\hline Tetraselmis sp. & CCNIOZ & - & - & - & - & - & - \\
\hline T. suecica & CCNIOZ & - & - & - & - & - & - \\
\hline
\end{tabular}

bly coincides with the granular-like structures which can be observed at the surface of the cell wall of $G$. aureolum, Gymnodinium nagasakiense and Gymnodinium mikimotoi by scanning electron microscopy (Partensky et al. 1988, Fukuyo et al. 1990, Vrieling unpubl. results). Further biochemical and immuno(cyto)-chemical electron microscopical studies are needed to reveal the exact nature and precise location of the cell surface antigens recognized by the different monoclonals.

The monoclonal antibodies were very specific in that they recognized only Gyrodinium (cf.) aureolum and the 2 morphologically closely related species Gymnodinium nagasakiense and Gymnodinium mikimotoi (Tables $3 \& 4$ ). The autofluorescence of heterotrophic dinoflagellates observed in field samples must not be interpretated as FITC fluorescence, since it was also observed in controls where the primary antibody was omitted. The strong specificity of the monoclonals implies that $G$. (cf.) aureolum and the 2 Gymnodinium species possess highly similar cell surface antigens. This suggests a taxonomic proximity or strong phylogenetic relationship of these species, although individual cell sizes, cell cycles and DNA con- 


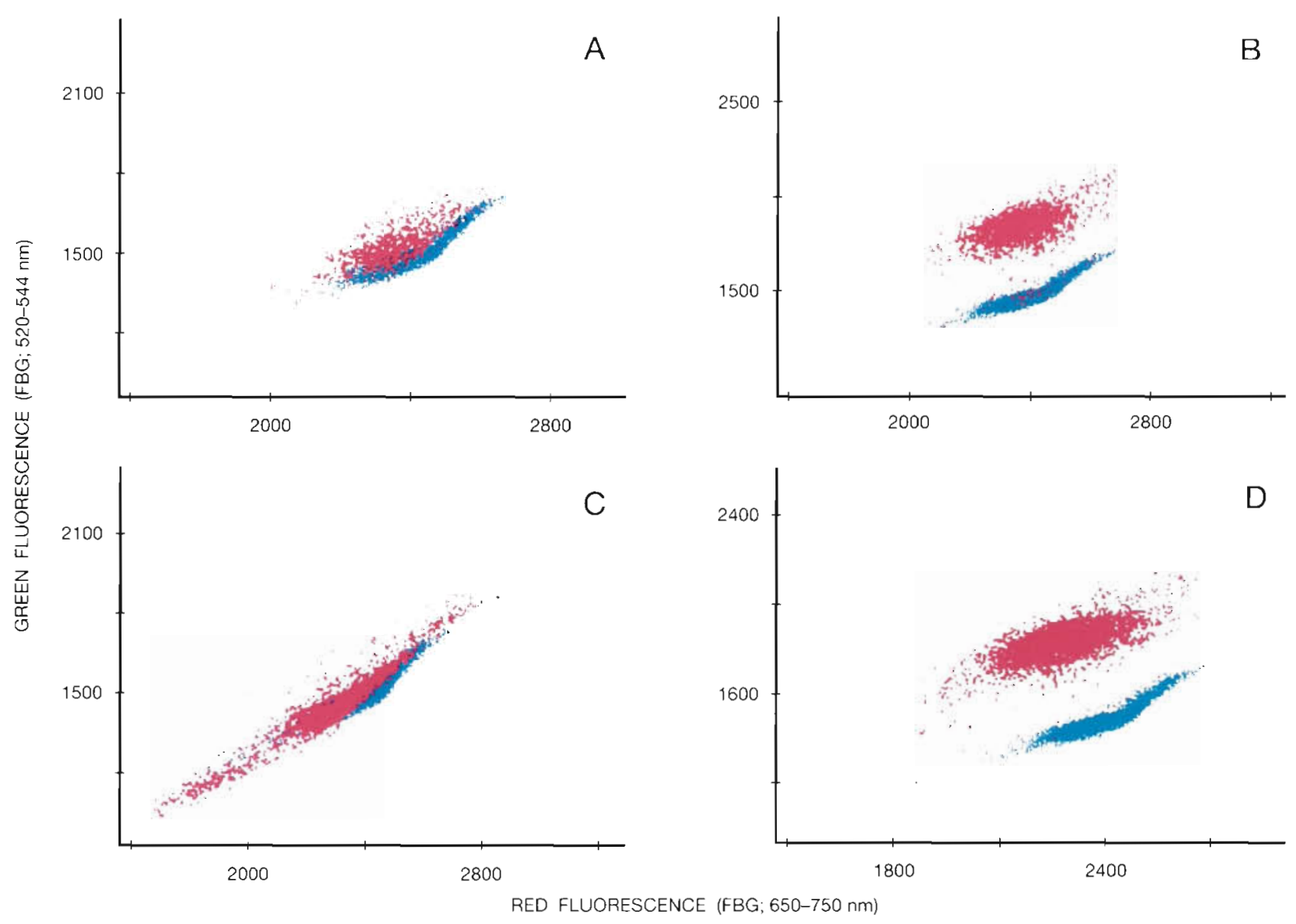

Fig. 2. Gyrodinium cf aureolum. Flow cytometric appearance of unlabeled (blue) and labeled (red) cells in bivariate plots of green FITC (FBG; 520 to $544 \mathrm{~nm}$ ) and red chlorophyll (FBR; 650 to $750 \mathrm{~nm}$ ) fluorescence. (A) Cells labeled with GA2 (Group I), (B) cells labeled with GA8 (Group II), (C) cells labeled with GA15 (Group III), and (D) cells labeled with a pooled antiserum (combined antibodies of GA2, GA8 \& GA15)
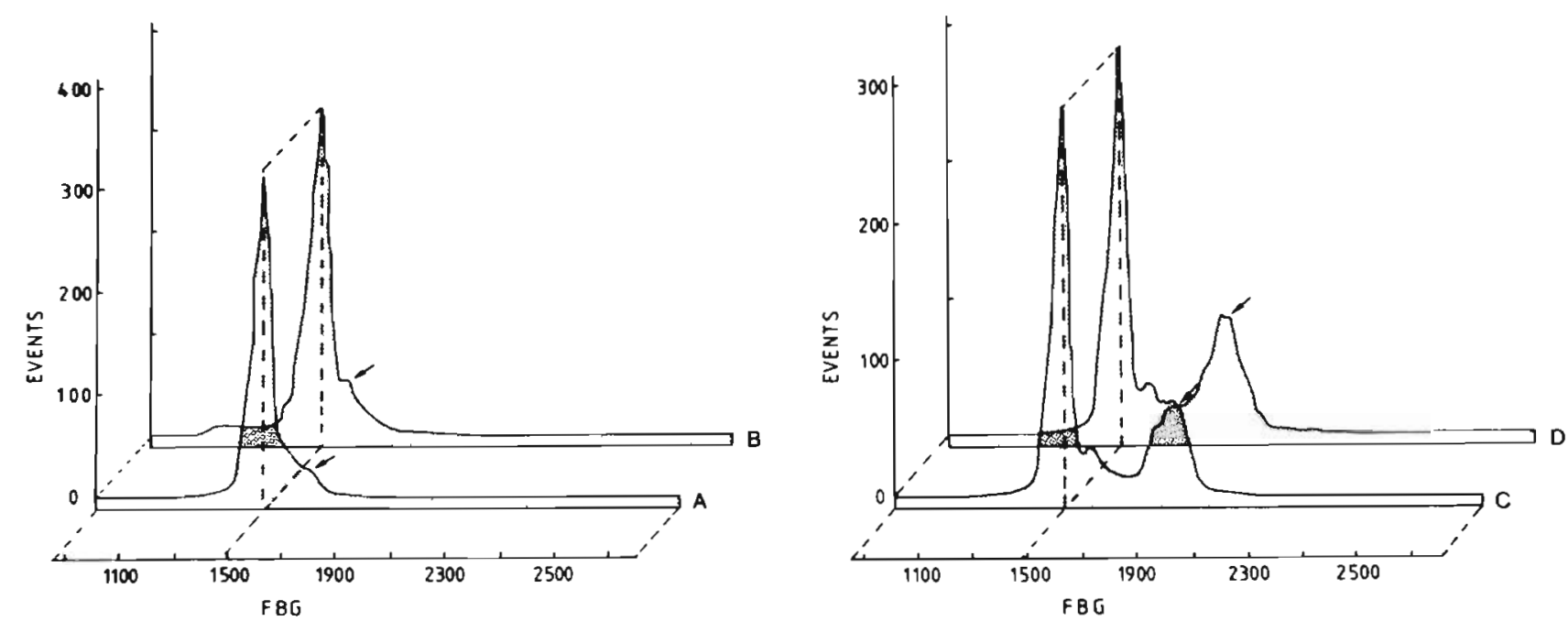

Fig. 3. Gyrodinium cf. aureolum. Histograms of events versus green FITC fluorescence (FBG) for labeled cells. The first peak of each histogram represents the FBG value of controls (unlabeled cells). The labeling conditions are as follows: (A) cells labeled with antibody GA2 (Group I), (B) cells labeled with GA.15 (Group III), (C) cells labeled with GA8 (Group II), and (D) cells labeled with the pooled serum (combined antibodies of GA2, GA8 \& GA15). Labeled cells in (A) to (D) are marked with arrows 
tents do vary (Partensky et al. 1988, Partensky \& Vaulot 1989, Partensky et al. 1991). Similar results have been obtained previously for polyclonal antisera recognizing toxic and non-toxic diatoms of the Nitzschia complex (Bates et al. 1993). Monoclonal antibodies prepared against cell surface antigens of G. nagasakiense by Nagasaki et al. (1991) showed an exclusive recognition of this species with respect to the species tested in this study, while our antibodies could not distinguish $G$. cf. aureolum from $G$. aureolum or the 2 morphologically similar Gymnodinium species. However, because of the morphological similarities and the potential toxicity of $G$. (cf.) aureolum and both Gymnodinium species, the cross-reaction will not have consequences for our monitoring program because these species are considered to be synonyms. The suggestion of a phylogenetic relationship could be tested by examining the homology of evolutionarily highly conserved ribosomal DNA or RNA sequences of $G$. (cf.) aureolum, G. nagasakiense, and $G$. mikimotoi. This method has already been used to study the biogeography of macroalgae (Bakker et al. 1992, Kooistra et al. 1992) and more recently to obtain markers for fine-scale analysis of populations and taxonomy of Alexandrium (Scholin et al. 1993).

For long-term storage of samples, we confirmed paraformaldehyde to be the best preservative both for indirect immunofluorescence microscopy as found by Campbell et al. (1988) and Bates et al. (1993) and for flow cytometry. Glutaraldehyde fixation not only reduces the binding capacity, resulting in a decrease of fluorescence intensity, but also induces an interfering yellow-greenish background fluorescence (Campbell et al. 1988). Although this background fluorescence does not necessarily hamper the microscopical identification of Gyrodinium aureolum (and the phylogenetically related species), it should be avoided when distinction of labeled cells by flow cytometry is pursued. The use of glutaraldehyde may also have other disadvantages, namely: (1) the occurrence of non-specific, non-immunochemical labeling of cells (Shapiro et al. 1989a, Bates et al. 1993) and (2) a decrease in pigment autofluorescence (Hall 1991, Vrieling et al. 1993a), thus resulting in reduction of fluorescence intensities which may fall below the detection limit of a flow cytometer (Landry et al. 1993). As mentioned before (Vrieling et al. 1993a), we use chlorophyll autofluorescence as the triggering parameter in our flow cytometric early warning system.

Traditionally, simple conservation of phytoplankton samples, especially for delayed examination of population composition, is achieved with Lugol's solution. We found that antigenicity was heavily affected for monoclonal antibodies of Groups I \& III (Table 2). Only monoclonals of Group II reacted with Lugol-fixed cells, although the fluorescence intensities decreased (Table 2) as has been shown previously (Anderson et al. 1990, Bates et al. 1993). In this case, microscopical identification and enumeration can be performed easily, while for flow cytometry forward or perpendicular light scattering has to be used as triggering parameter. The latter results in a significant distinction of labeled cells from unlabeled ones (unpubi. results). However, interference of the FITC label with green autofluorescence of cell walls of heterotrophic dinoflagellates (Shapiro et al. 1989b) and particulate matter influence flow cytometric detection, as has been observed in field samples. Storing intact cells by freezing only is not enough to maintain sufficient antigenic sites recognized by monoclonal antisera of Group III. Furthermore, due to the washing steps during the immunochemical procedure, the overall cell morphology is often affected severely and cells may even lose their chloroplasts. Our results indicated that a prefixation step (we prefer paraformaldehyde) is essential prior to freezing of cells in order to create conditions that allow a subsequent convenient flow cytometric analysis; these results are in line with earlier observations by Vaulot et al. (1989).

Finally, previous studies revealed that at the highest fluorescence intensities of the applied probe, identification of species by flow cytometry is unequivocal (Vrieling et al. 1993a). Therefore, we suggest that paraformaldehyde fixation of samples be combined with immunochemical labeling of Gyrodinium (cf.) aureolum and the 2 phylogenetically related species Gymnodinium nagasakiense and Gymnodinium mikimotoi followed by immunochemical labeling using monoclonal antibodies of Group II or the pooled antiserum. Routine (immuno)flow cytometric identification and enumeration of these species in mixed populations can be readily done. With regard to efficiency, the monoclonal antibodies of Groups I \& III are less convenient for flow cytometric identification, although fluorescence intensities can be enhanced by applying the biotin-streptavidin system (Vrieling et al. 1993a). Nevertheless, both groups of monoclonals are useful for microscopical observations and/or biochemical investigations. The monoclonals of Group III may be especially useful for a study of the nature and significance of the granular-like structures.

In conclusion, the use of immunochemistry in an early warning system for the presence of Gyrodinium aureolum in coastal waters appears to be feasible. Even in mixed populations (field samples) G. aureolum could be detected properly. Because of the specificity of the monoclonal antibodies which have been prepared, we should be able to use the method to quantify recovery of $G$. aureolum after immunochemical labeling by using spiked populations. 
Acknowledgements. We thank R. Groenewoud and M. de Jong of MCA Development BV (Groningen, The Netherlands) for assistance with the preparation of the monoclonal antisera We are grateful to Dr A. Buma (Marine Department, University of Groningen (RUG), The Netherlands) and A. Noordeloos (Neth. Inst. of Sea Res. (NIOZ), Texel, The Netherlands) for providing cultures of several phytoplankton species of their culture collection. Gyrodinium and Gymnodinium strains were kindly supplied by Drs D. M. Anderson (WHOl, Woods Hole, MA, USA), P. Gentien (IFREMER, Brest, France), G. M. Hallegraeff (University of Tasmania, Hobart, Australia), D. Jacobson and R. A. Andersen (Bigelow Lab. of Ocean Science, West Boothbay Harbor, ME, USA), J. Larsen (Bot. Inst., Copenhagen, Denmark), and K. Nagasaki (Nansei Nat. Fish. Res. Inst., Hiroshima, Japan). We thank G. Vriezekolk (Tidal Waters Division for performing the flow cytometric experiments and J. Zagers for preparing the figures.

\section{LITERATURE CITED}

Anderson, D. M. (1989). Toxic algal blooms and red tides: a global perspective. In: Okaichi, T., Anderson, D. M., Nemoto, T. (eds.) Red tides: biology, environmental sciences, and toxicology. Elsevier, New York, p. 11-16

Anderson, D. M., Kulis, D. M., Cosper, E. M. (1990). Immunofluorescent detection of the brown tide organism, Aureococcus anophagefferens. In: Bricel, V. M., Carpenter, E. J (eds.) Novel phytoplankton blooms: causes and impacts of recurrent brown tides and other unusual blooms Springer-Verlag, Berlin, p. 213-228

Bakker, F. T., Olsen, J. L., Stam, W., van den Hoek, C. (1992) Nuclear ribosomal DNA internal transcribed spacer regions (ITS1 and ITS2) define discrete biogeographic groups in Cladophora albida (Chlorophyta). J. Phycol. 28 $839-845$

Bates, S. S., Léger, C., Keafer, B. A., Anderson, D. M. (1993). Discrimination between domoic-acid-producing and nontoxic forms of the diatom Pseudonitzschia pungens using immunofluorescence. Mar. Ecol. Prog. Ser. 101: 185-195

Campbell, L., Shapiro, L. P., Haugen, E. M., Morris, L. (1988). Immunochemical approaches to the identification of the ultraplankton: assets and limitations. In: Cosper, E. M., Carpenter, E. J., Bricelj, M. (eds.) Novel phytoplankton blooms. Lecture notes on coastal and estuarine studies. Springer Verlag, New York, p. 39-56

Dubelaar, G. B. J., Groenewegen, A. C., Stokdijk, W., van den Engh, G. J., Visser, J. W. M. (1989). The optical plankton analyzer (OPA): a flow cytometer for plankton analysis. II: Specifications. Cytometry 10: 529-539

Fukuyo, Y., Takano, H., Chihara, M., Matsuoka, K. (1990). Red Tide Organisms in Japan: an illustrated taxonomic guide. Uchida Rokakuho Co. Ltd, Tokyo

Guillard, R. R. L., Ryther, J. H. (1962). Studies of marine planktonic diatoms. I. Cyclotella nana Hustedt and Detonula confervacea Cleve. Gran. Can. J. Microbiol. 8: $229-239$

Hall, J. A. (1991). Long-term preservation of picoplankton for counting by fluorescence microscopy. Br. Phycol. J. 26: $169-174$

Hallegraeff, G. M. (1993). A review of harmful algal blooms and their apparent global increase. Phycologia 32: 79-99

Hiroishi, S., Uchida, A., Nagasaki, K., Ishida, Y. (1988). A new method for identification of inter-and intra-species of the red tide algae Chattonella antiqua and Chattonella marina (Raphidophyceae) by means of monoclonal antibodies. J. Phycol. 24: 442-444
Kat, M. (1985). Dinophysis acuminata blooms, the distinct cause of mussel poisoning. In: Anderson, D. M., White, A. W., Baden, D. G. (eds.) Toxic dinoflagellates. Elsevier, New York, p. 95-100

Kat, M. (1987). Diarrhetic mussel poisoning. Measures and consequences in the Netherlands. Dutch Rapp. 187: 83-88

Kooistra, W. H. C. F. Stam, W. T., Olsen, J. L., van den Hoek, C. (1992). Biogeography of Claophoropsis membranacea based on comparisons of nuclear rDNA. ITS sequences. J. Phycol. 28: 660-668

Landry, M., Kirshtein, J., Monger, B. (1993). Quantitative enumeration of paraformaldehyde preserved Prochlorococcus by flow cytometry. Signal \& Noise, Individual Particle Analysis in Aquatic Sciences 6(1): 3

Leewis, R. J. (1985). Phytoplankton off the Dutch coast. A baseline study on the temporal and spatial distribution of species in 1974 and 1975. Ph.D. thesis, University of Nijmegen

Nagasaki, K., Uchida, A., Hiroishi, S., Ishida, Y (1989). Identification of red tide algae Chattonella marina and Chattonella antiqua by means of monoclonal antibodies. In: Miyachi, S., Karube, I., Ishida, Y. (eds.) Current topics in marine biotechnology. Fuji Technology Press, Tokyo, p. 161-164

Nagasaki, K., Uchida, A., Ishida, Y. (1991). A monoclonal antibody which recognizes the cell surface of red tide alga Gymnodinium nagasakiense. Nippon Suisan Gakk. 57 : $1211-1214$

Partensky, F. Vaulot, D. (1989) Cell size differentiation in the bloom-forming dinoflagellate Gymnodinium cf. nagasakiense. J. Phycol. 25: 741-750

Partensky, F., Vaulot, D., Couté, A., Sournia, A. (1988). Morphological and nuclear analysis of the bloom-forming dinoflagellates Gyrodinium cf. aureolum and Gymnodinium nagasakiense. J. Phycol. 24:408-415

Partensky, F., Vaulot, D., Videau, C. (1991). Growth and cell cycle of two closely related red tide-forming dinoflagellates: Gymnodinium nagasakiense and $G$. cf. nagasakiense. J. Phycol. 27: 733-742

Peeters, J. C. H., Dubelaar, G. B. J., Ringelberg, J., Visser, J. W. M. (1989). The optical plankton analyzer (OPA): a flow cytometer for plankton analysis. I: Design considerations Cytometry 10:522-528

Peperzak, L. (1990). Toxic algae in the stratified Dutch part of the North Sea in 1989. Red Tide Newslett. 3: 2-3

Reid, P. C., Lancelot, C., Gieskes, W. W. C., Hagmeier, E., Weichart. G. (1990). Phytoplankton of the North Sea and its dynamics: a review. Neth. J. Sea Res. 26: 295-331

Sako, Y., Adachi, M., Ishida, Y (1992). Preparation and characterization of monoclonal antibodies to Alexandrium species. In: Smayda, T. J., Shimizu, Y (eds.) Toxic phytoplankton blooms in the sea. Elsevier, Amsterdam, p. 87-93

Scholin, C. A., Anderson, D. M., Sogin, M. L. (1993). Two distinct small-subunit ribosomal RNA genes in the North American toxic dinoflagellate Alexandrium fundyense (Dinophyceae). J. Phycol. 29: 209-216

Shapiro, L. P., Campbell, L., Haugen, E. M. (1989a). Immunochemical recognition of phytoplankton species. Mar. Ecol. Prog. Ser. 57: 219-224

Shapiro, L. P., Haugen, E. M., Carpenter, E. J. (1989b). Occurrence and abundance of green-fluorescing dinoflagellates in surface waters of the Northwest Atlantic and Northeast Pacific Oceans. J. Phycol. 25: 189-191

Smayda, T J. (1989). Novel and nuisance phytoplankton blooms in the sea: evidence for a global epidemic. In: Granéli, E., Sundström, B., Edler, L., Anderson, D. M. (eds.) Toxic marine phytoplankton. Elsevier, Amster dam, p. 29-39 Vaulot, D., Courties, C., Partensky, F. (1989). A simple method 
to preserve oceanic phytoplankton for flow cytometric analysis. Cytometry 10:629-635

Vrieling E. G., Draaijer, A., van Zeijl, W. J. M., Peperzak, L., Gieskes, W. W. C., Veenhuis, M. (1993a). The effect of labeling intensity, estimated by real time confocal laser scanning microscopy, on flow cytometric appearance and identification of immunochemically labeled marine dino-

This article was submitted to the editor flagellates. J. Phycol. 29: 180-188

Vrieling, E. G., Gieskes, W. W. C., Colijn, F., Hofstraat, J. W., Peperzak, L. Veenhuis, M. (1993b). Immunochemical identification of toxic marine algae: first results with Prorocentrum micans as model organism. In: Smayda, T. J., Shimizu, Y (eds.) Toxic phytoplankton blooms in the sea. Elsevier, Amsterdam, p. 925-931

Manuscript first received: July 27, 1993

Revised version accepted: October 1, 1993 